\title{
STABILITAS, HAMBATAN DAN OLAH GERAK KAPAL IKAN MULTI PURPOSE NET/LINE HAULER 20 GT BERDASARKAN KAJIAN UKURAN DAN BENTUK KASKO KAPAL
}

\author{
Stability, Resistance and Seakeeping Performance of A 20 GT Fishing Boat Based on the \\ Boat Dimension and Hull Form Analysis \\ Oleh: \\ Arif Fadillah ${ }^{*}$, Shanty Manullang2, Rizky Irvana ${ }^{3}$ \\ 1 Jurusan Teknik Perkapalan, Fakultas Teknologi Kelautan, Universitas Darma Persada \\ Jl. Taman Malaka Selatan, RT.8/RW.6, Pd. Klp., Duren Sawit, Kota Jakarta Timur, Daerah Khusus Ibukota Jakarta \\ 13450.arif_fadillah@ftk.unsada.ac.id \\ $2 J u r u s a n$ Teknik Perkapalan, Fakultas Teknologi Kelautan, Universitas Darma Persada \\ Jl. Taman Malaka Selatan, RT.8/RW.6, Pd. Klp., Duren Sawit, Kota Jakarta Timur, Daerah Khusus Ibukota Jakarta \\ 13450. shanty_manullang@ftk.unsada.ac.id \\ 3 Jurusan Teknik Perkapalan, Fakultas Teknologi Kelautan, Universitas Darma Persada \\ Jl. Taman Malaka Selatan, RT.8/RW.6, Pd. Klp., Duren Sawit, Kota Jakarta Timur, Daerah Khusus Ibukota Jakarta \\ 13450.rizky_irvana@ftk.unsada.ac.id \\ *Korespondensi: arif_fadillah@ftk.unsada.ac.id
}

Diterima: 19 April 2019; Disetujui: 1 Oktober 2019

\begin{abstract}
Fishing boats are used in capturing or collecting aquatic resources. As a means of production, the boat should meet various conditions of seaworthiness i.e. good stability, good seakeeping ability and minimum resistance. Those criteria can be identified when the boat size and the hull form are designed. This study investigates the effect of the boat dimension and the hull form on the stability, resistance and seekeeping ability. Various sizes and hull shapes of a 20 GT fishing boat were simulated, and their performances were compared to the IMO standard. The results suggest that the minimum breadth $(B)$ - draft (d) ratio which meets the stability criterion is 2.50 , while the ratio of the center of gravity distance from the keel (KG) and the depth (D) of the boat is 0.65 . Furthermore, for the boat with a higher $B$ and $D$ ratio, its resistance is relatively smaller. In terms of seakeeping ability, particularly roll and pitch motions, $U$ type bottom performed better than the Akatsuki bottom.
\end{abstract}

Keywords: fishing vessel, sea keeping, ship hull, stability, resistance

\section{ABSTRAK}

Kapal ikan digunakan dalam penangkapan atau pengumpulan sumber daya perairan. Sebagai sarana produksi, kapal ikan harus memenuhi syarat kelayakan, yang diantaranya adalah memiliki kualitas stabilitas dan olah gerak yang baik serta hambatan gerak yang minimum. Ketiga kondisi tersebut dapat diidentifikasi pada saat proses perancangan ukuran dan bentuk kapal. Penelitian ini bertujuan mengkaji pengaruh ukuran dan bentuk kapal terhadap nilai stabilitas, olah gerak dan hambatan yang dihasillkan oleh kapal. Studi dilakukan dengan mensimulasikan berbagai ukuran dan bentuk kapal ikan 20 GT dan membandingkan hasilnya dengan standard yang ditetapkan oleh IMO. Berdasarkan hasil kajian, diketahui bahwa rasio lebar (B)-draft (d) kapal minimum yang memenuhi kriteria stabilitas adalah 2,50 dengan rasio posisi titik berat (KG) dan tinggi kapal (D) adalah 0,65. Selanjutnya, untuk badan kapal dengan rasio B/D yang besar, tahanan kapalnya akan relatif lebih 
kecil. Dalam hal olah gerak kapal khususnya roll dan pitch motion, tipe U lebih baik dari pada tipe Akatsuki Bottom.

Kata kunci: kapal ikan, olah gerak, lambung kapal, stabilitas, hambatan

\section{PENDAHULUAN}

Kapal ikan di Indonesia mempunyai bentuk kasko yang beraneka ragam. Secara teori, bentuk kasko kapal dipengaruhi oleh karakteristik perairan dan metode pengoperasian alat tangkap yang dioperasikannya (Fyson 1985). Metode pengoperasian alat tangkap statik, lebih menguntungkan jika memiliki kasko berbentuk $U$ (U-type) jenis kapal ini memiliki stabilitas yang tinggi dalam hal pengoperasiannya.

Sebaliknya kasko berbentuk $\mathrm{V}$ (V-type) sangat cocok untuk operasi penangkapan yang bersifat dinamik, sehingga faktor kecepatan dan kemampuan olah gerak menjadi syarat mutlak dalam pengoperasian kapal ini. Pengoperasian alat tangkap yang dinamis, menjadi salah satu faktor yang akan mempengaruhi stabilitas. Hal ini disebabkan pergerakan alat tangkap pada saat berlayar menghasilkan momen-momen penggangu yang mengakibatkan kemiringan kapal (Mantari et al. 2011). Dengan demikian dapat dikatakan bahwa bentuk kasko merupakan salah satu faktor teknis yang berperan terhadap keberhasilan dalam pengoperasian kapal di laut. Perikanan tangkap adalah salah kegiatan yang dilakukan di laut dengan jumlah kecelakaan terbanyak di dunia. Hal ini disebabkan karena banyak nelayan yang belum memperhitungkan faktor stabilitas dalam penangkapan ikan (Caamano et al. 2016).

Pada tahapan awal perancangan, yaitu penentuan ukuran utama kapal serta karakteristik geometri lainnya, kemampuan unjuk kerja kapal seperti tahanan dan propulsi maupun yang terkait dengan keselamatan seperti stabilitas, maneuvering sudah harus bisa diprediksi (Jung et al. 2018). Tingkat keamanan sangat diperlukan dalam mempertimbangkan stabilitas seperti mengevaluasi perhitungan stabilitas dan menentukan langkah-langkah yang tepat saat tahap desain awal. Langkah ini perlu dilakukan dalam bentuk alternatif desain untuk mendapatkan desain yang optimal (hull-shape, subdivisi, dll) dan kondisi-kondisi dalam membawa muatan (Boulougouris et al. 2016).

Dalam perkapalan, konsep "Stabilitas" memiliki arti yang luas, merangkap arti fundamental stabilitas terhadap keselamatan kapal. Oleh karena itu, stabilitas kapal sangat penting karena memiliki implikasi terhadap desain dan operasi kapal pada saat berlayar (Bačkalov et al. 2016). Untuk mendapatkan nilai stabilitas, kemampuan olah gerak dan hambatan gerak yang sesuai dengan kebutuhan kapal penangkap ikan, maka perlu dilakukan kajian untuk menentukan nilai rasio dimensi utama kapal yang optimal. Sebagaimana dikatakan oleh Paroka (2018), nilai rasio dimensi utama yang tepat, dapat dijadikan sebagai kontrol desain kapal yang akan dibangun saat ini dan di masa yang akan datang.

Tujuan dari penelitian ini adalah mendapatkan nilai stabilitas, hambatan, dan seakeeping sebagai pengaruh karakteristik geometri kapal ikan. Diharapkan dari hasil kajian ini, prediksi awal kondisi stabilitas kapal, hambatan dapat diketahui pada tahapan awal perancangan.

Studi ini dilakukan dengan mensimulasi kapal ikan 20 GT, dengan bentuk kasko $U$ dan hardchin. Penggunaan istilah hardchin adalah mengacu pada istilah yang digunakan dalam Rouf dan Novita (2006). Sebagai bagian program pemerintah, Kementerian Kelautan dan Perikanan (KKP) menyediakan kapal penangkap ikan dengan ukuran 3, 5, 10, 20 dan 30 GT (Direktorat Jenderal Perikanan Tangkap), dengan berbagai tipe alat tangkap. Pada kegiatan penelitian ini dilakukan hanya pada kapal ikan Multi Purpose Net/ Line Hauler 20 GT untuk lambung $U$ dan hardchin yang dibangun oleh KKP. Kapal ikan tersebut dibangun dan digunakan untuk seluruh wilayah penangkapan ikan di Indonesia.

\section{METODE}

Metode yang di gunakan pada penelitian ini adalah studi kasus dan simulasi numerik. Subyek penelitian adalah desain kapal ikan Multi Purpose Net/Line Hauler 20 GT untuk lambung tipe $U$ dan hardchin yang dibangun oleh KKP. Jenis data yang digunakan sebagaimana disajikan pada Tabel 1. Data-data tersebut diperoleh dari data desain kapal yang dirancang oleh KKP.

Pengolahan data kapal dilakukan dengan menggunakan software Maxsurf. Analisis data pada perhitungan stabilitas kapal digunakan formula dari A.N Krylof.

$F_{B}=g \Delta=\rho g \nabla$ 
dengan: $F_{B}=$ buoyancy, $g=$ gravitasi, $\Delta=$ displasemen kapal, $\rho=$ masa jenis.

Lengan stabilitas statis dihitung dengan:

$G Z=y_{B \varphi} \cos \varphi+Z_{B \varphi}-K g \sin \varphi$

dengan: $y_{B \varphi}, Z_{B \varphi}$ adalah koordinat dari pusat daya apung.

Untuk mengukur momen penegak pada semua sudut kemiringan memakai formula:

$M_{R}=g \Delta G Z$

Pada perhitungan hambatan kapal digunakan metode Holtrop Mannen.

$R_{\text {total }}=R_{F}\left(1+k_{1}\right)+R_{A P P}+R_{W}+R_{B}+R_{T R}+R_{A . .(4)}$ dengan:

$R_{F} \quad=$ tahanan gesek menurut formula ITTC 1957

$1+k_{1}=$ faktor lambung

$R_{\text {APP }}=$ tahanan tambahan

$R_{W}=$ tahanan gelombang

$R_{B}=$ tambahan tekanan dari Bulbous

$R_{T R}=$ Tahanan tambahan dari transom stren dan

$R_{A}=$ korelasi tahanan model-kapal sebenarnya.

Perhitungan spektrum gelombang menggunakan metode JONSWAP, dimana (Hasselmann et al. 1978):

$S(\omega)=\frac{\alpha g^{2}}{\omega^{5}} \exp \left[-\beta \frac{\omega_{p}^{4}}{\omega^{4}}\right] \gamma^{\alpha}$

dengan:

$\alpha=\left\{\begin{array}{l}0,07 \text { if } \omega \leq \omega_{p} \\ 0,09 \text { if } \omega>\omega_{p}\end{array}\right.$

$\beta=\frac{5}{4}$

Tabel 1 Ukuran utama kapal

\begin{tabular}{lccc}
\hline & \multicolumn{1}{c}{ Item } & Satuan & 20 GT \\
\hline Panjang Kapal & (Loa) & $\mathrm{M}$ & 17 \\
Lebar & (B) & $\mathrm{M}$ & 3,6 \\
Tinggi & (D) & $\mathrm{m}$ & 1,9 \\
Sarat & (d) & $\mathrm{m}$ & 1,3 \\
Lambung timbul & $(\mathrm{fb})$ & $\mathrm{m}$ & 0,6 \\
Koefisien blok (Cb) & - & 0,555 \\
Koefisien blok (Cb) V & - & 0,547 \\
B/T & - & 2,76 \\
fb/B & - & 0,16 \\
Awak & Orang & 7 \\
Kecepatan (Vs) & Knot & 9 \\
\hline
\end{tabular}

A = konstanta yang berhubungan dengan kecepatan angin dan Panjang fetch. Nilai-nilai khas di utara laut utara berada di kisaran $0,0081-0,01$.

$\omega=$ frekuensi gelombang

$\omega_{p}=$ gelombang frekuensi puncak

Kriteria olah gerak kapal menggunakan seakeeping (Tello 2010). Pada Tabel 2 disajikan kriteria seakeeping. Untuk dapat mengamati pengaruh perbandingan antara lebar (B) dan sarat kapal (d) terhadap stabilitas, sarat kapal divariasikan dengan lebar yang tetap. Variasi sarat kapal dilakukan dengan mengambil 2 (dua) sarat yang lebih kecil dan 2 (dua) sarat yang lebih besar dari sarat desain, seperti yang terlihat pada Tabel 3. Metode yang sama dilakukan untuk mengamati pengaruh perbandingan antara lambung timbul dan lebar kapal. Titik berat kapal (KG) juga divariasikan dari titik berat terendah yang mungkin terjadi sampai pada titik berat sama dengan tinggi kapal. Pada setiap variasi rasio, lengan stabilitas kapal dihitung dan dievaluasi dengan kriteria stabilitas IMO (IMO 2008). Kriteria IMO yang digunakan disajikan pada Tabel 4.

Pengaruh bangunan atas terhadap lengan stabilitas tidak diperhitungkan karena pengaruhnya sangat kecil. Berdasarkan hasil perhitungan lengan stabilitas dan hasil evaluasi terhadap kriteria stabilitas IMO, perubahan karakteristik lengan stabilitas sebagai fungsi dari dua perbandingan ukuran utama dapat diperoleh. Pengaruh momen crew, momen cikar serta kemungkinan terjadinya pergeseran beban ketika kapal oleng dengan sudut yang besar tidak diperhitungkan dalam analisis ini.

Tabel 2 Kriteria seakeeping

\begin{tabular}{lc}
\hline \multicolumn{1}{c}{ Criterion } & Prescribe maximumvalue \\
\hline Roll & $6 \mathrm{deg}$ \\
Pitch & $3 \mathrm{deg}$ \\
Lateral acceleration (at working deck AP \& FP & $0,1 \mathrm{~g}$ \\
Vertical acceleration (at working deck AP \& FP & $0,2 \mathrm{~g}$ \\
\hline
\end{tabular}

Sumber: Tello 2010 
Tabel 3 Rasio B/d

\begin{tabular}{ccc}
\hline $\mathrm{B}$ & $\mathrm{d}$ & $\mathrm{B} / \mathrm{d}$ \\
\hline 3,6 & 1,52 & 2,36 \\
3,6 & 1,4 & 2,56 \\
3,6 & 1,3 & 2,76 \\
3,6 & 1,21 & 2,96 \\
3.6 & 1,13 & 3,16 \\
\hline
\end{tabular}

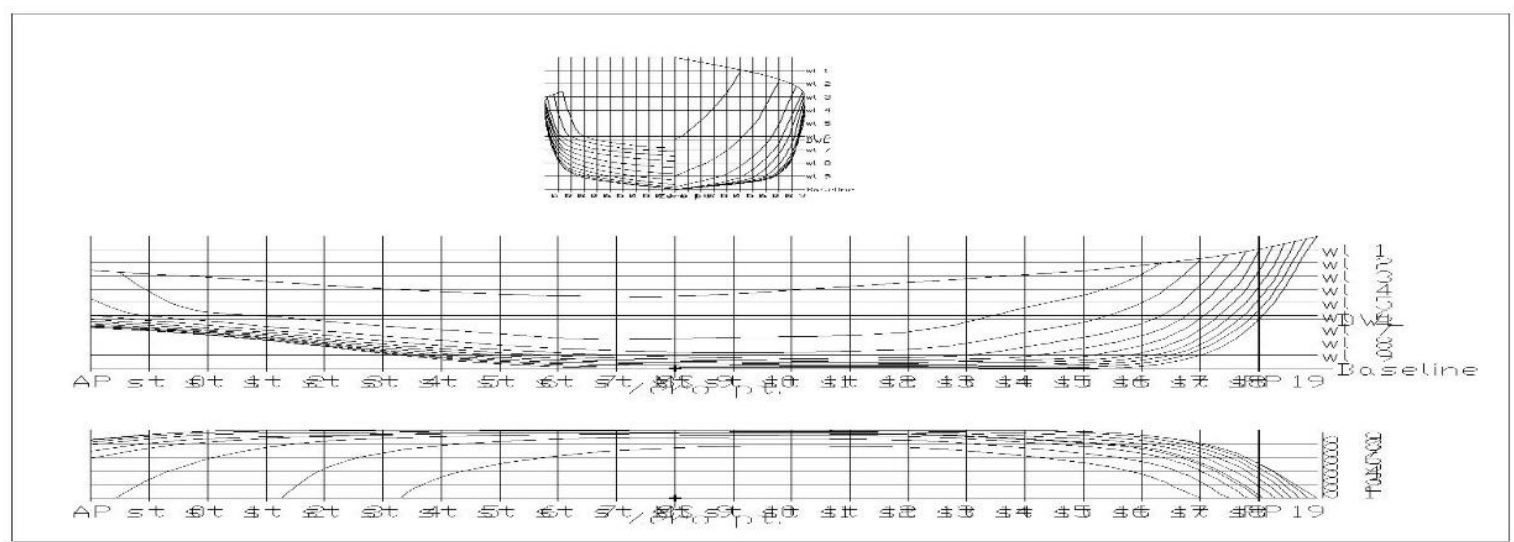

a) Type U

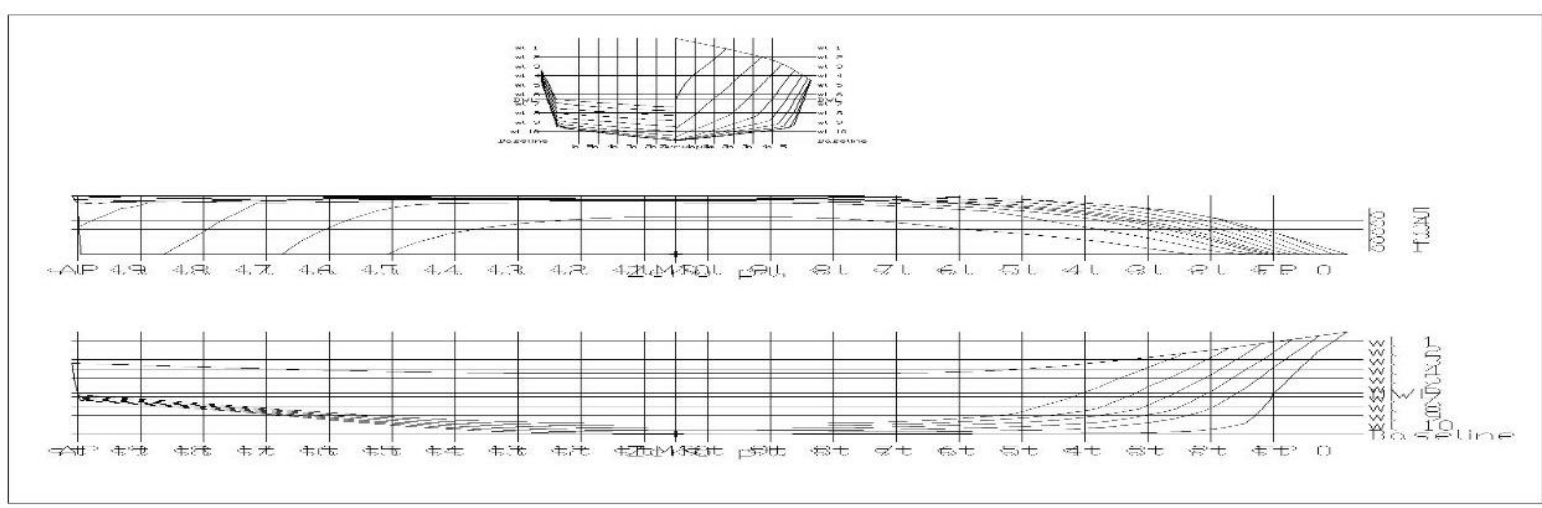

b) Type hardchin

Gambar 1 Lines plan kapal multi purpose net/line hauler 20 GT

Tabel 4 Kriteria IMO

\begin{tabular}{llcc}
\hline \multicolumn{1}{c}{ Code } & \multicolumn{1}{c}{ Criteria } & Value & Units \\
\hline A.749(18) Ch3 & 3.1.2.1: Area 0 to 30 & 3,1513 & $\mathrm{~m} . \mathrm{deg}$ \\
A.749(18) Ch3 & 3.1.2.1: Area 0 to 40 & 5,1566 & $\mathrm{~m} . \mathrm{deg}$ \\
A.749(18) Ch3 & 3.1.2.1: Area 30 to 40 & 1,7189 & $\mathrm{~m} . \mathrm{deg}$ \\
A.749(18) Ch3 & 3.1.2.2: Max GZ at 30 or greater & 0,200 & $\mathrm{~m}$ \\
A.749(18) Ch3 & 3.1.2.3: Angle of maximum GZ & 25,0 & $\mathrm{deg}$ \\
4.2 Fishing vessel & 4.2.3.1: Initial GMt for vessels $>=24 \mathrm{~m}$ in length & 0,350 & $\mathrm{~m}$ \\
\hline
\end{tabular}

\section{HASIL}

Susanto et al. (2011) menyampaikan bahwa, parameter yang dapat digunakan untuk menentukan ukuran kapal adalah rasio dimensi utama yang sesuai dengan alat tangkap yang akan digunakan dan daerah penangkapan yang akan dituju. Penggunaan data rasio dimensi utama akan lebih baik bila diikuti dengan perhitungan stabilitas, sehingga kapal yang dihasilkan memiliki kualifikasi sesuai dengan tujuan pembuatannya.

Dari kedua gambar di bawah menunjukkan bahwa semakin besar rasio lebar dan sarat kapal, lengan stabilitas akan semakin besar. Sesuai dengan hasil penelitian Paroka (2018) yang menyatakan bahwa semakin besar rasio maka 
luasan di bawah lengan stabilitas akan naik. Dengan demikian, luas di bawah kurva atau lengan stabilitas tersebut juga akan semakin besar. Makin kecil sarat kapal, sudut kemiringan sampai tepi geladak terbenam ke dalam air juga akan semakin besar. Lebar garis air kapal akan semakin besar dengan bertambahnya sudut kemiringan sampai sudut kemiringan dimana tepi geladak terbenam dalam air. Akibatnya, jari-jari metacentra (MB) semakin besar sehingga lengan stabilitas juga menjadi semakin besar dengan bertambahnya rasio lebar (B) dan sarat kapal (d). Kondisi ini dibuktikan dari grafik stabilitas yang disajikan pada Gambar 2.

Hal ini disebabkan karena perubahan momen inersia pada tinggi garis air tertentu yang akan menjadi lebih kecil ketika sudut kemiringan lebih besar. Momen inersia yang dimaksud adalah momen inersia memanjang terhadap sumbu melintang yang melalui titik berat bidang garis air. Penurunan momen inersia garis air menyebabkan jari-jari metacentre kapal berkurang. Dampak semakin kecilnya jari-jari metacentre (MB), mengakibatkan lengan stabilitas juga semakin kecil.

Sudut kemiringan pada posisi angle of vanishing stability $(\mathrm{GZ}=0)$ akan semakin besar dengan bertambahnya rasio lebar dan sarat kapal. Perubahan angle of vanishing stability akibat perubahan rasio lebar dan sarat kapal tersebut juga disebabkan oleh perubahan karakteristik garis. Penempatan muatan di bawah lantai dek kapal, dapat meningkatkan kualitas stabilitas kapal, sebaiknya muatan di tempatkan di bawah lantai dek kapal tetapi kelebihan muatan di atas kapal sebaiknya dihindari (Novita et al. 2014). Kapal terbalik adalah fenomena fatal yang disebabkan oleh stabilitas kapal yang tidak mencukupi dalam kondisi operasi aktual (Krata, 2008). Rawson and Tupper (1983) menyatakan, selang stabilitas (range of stability), yaitu selang dimana nilai GZ adalah positif, biasanya berada pada selang sudut 00 sampai 900 , dimana kapal akan kembali ke posisi semula setelah momen yang menyebabkan kemiringan hilang. Secara umum luas di bawah kurva lengan stabilitas untuk semua rasio lebar dan sarat kapal memenuhi kriteria stabilitas IMO, seperti sampel yang telah dianalisis di pada Tabel 5 . Tabel 5 adalah data hasil penelitian yang dilakukan terhadap kapal yang diteliti. Diambil rasio 2,76 untuk sampel luas kurva yang memenuhi kriteria dari IMO.

\section{Perbandingan Stabilitas Tipe U dan Hardchin}

Rasio yang sama seperti pada Tabel 3 digunakan untuk masing-masing tipe kapal yaitu tipe $U$ dan hardchin untuk mengetahui stabilitas kapal tipe apa yang paling baik. Dari Gambar 3 menunjukkan bahwa stabilitas dengan lambung tipe U lebih baik dibandingkan tipe hardchin. Lengan stabilitas untuk kapal tipe $U$ mempunyai area yang lebih luas dibandingkan dengan kapal tipe hardchin. Hal ini disebabkan karena perbedaan bentuk penampang dimana bentuk bagian penampang $U$ lebih lebar dibandingkan bentuk penampang hardchin. Kondisi ini mengakibatkan nilai BM atau radius metacentre pada sudut tertentu menjadi semakin besar yang mengakibatkan lengan stabilitas menjadi semakin besar pula.

Besarnya nilai BM dipengaruhi oleh momen inersia yang besar pada sudut tertentu. Seperti yang dijelaskan sebelumnya bahwa rasio lebar dan sarat yang besar atau pada sarat yang kecil mempunyai momen inersia yang besar, begitu pula sebaliknya.

\section{Pengaruh Rasio Titik Berat dan Tinggi Kapal}

Titik berat (center of gravity) dikenal dengan titik $\mathrm{G}$ dari sebuah kapal, merupakan titik tangkap dari semua gaya-gaya yang menekan ke bawah terhadap kapal. Letak titik G di kapal dapat diketahui dengan meninjau semua pembagian bobot di kapal. Semakin banyak bobot yang diletakkan di bagian atas dek kapal, maka makin tinggilah letak titik G-nya terhadap lunas kapal. Pada Gambar 4 menunjukkan bahwa makin besar rasio titik berat dan tinggi kapal, makin kecil rasio lebar dan sarat kapal.

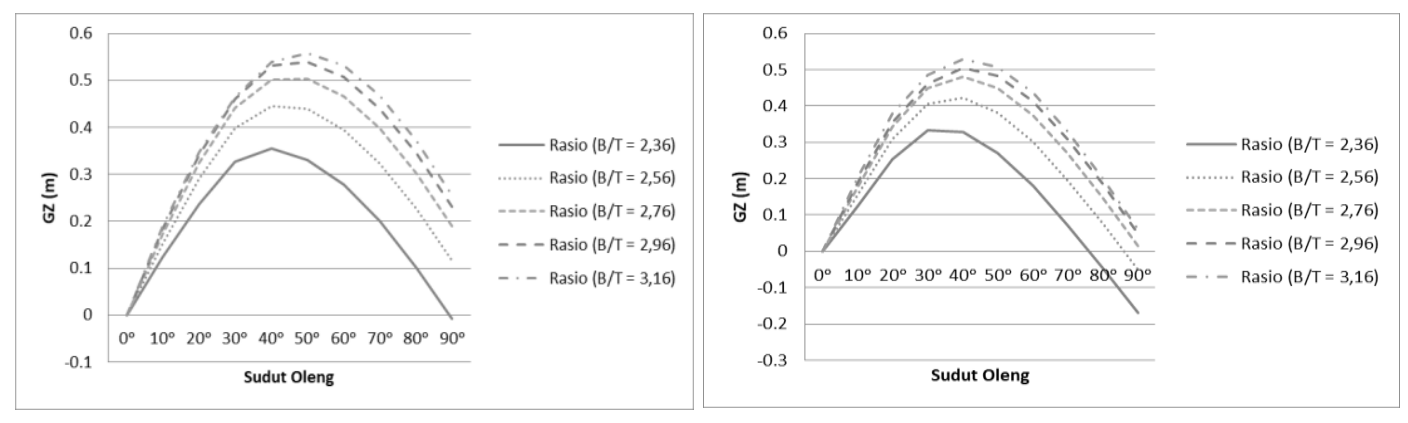

Gambar 2 Lengan stabilitas kapal 20 GT U dan hardchin 
Hal ini menunjukkan bahwa nilai KG berbanding terbalik dengan nilai GM. Jika nilai KG besar maka nilai GM menjadi kecil. Rasio lebar dan sarat kapal maksimum yang memenuhi kriteria stabilitas sebuah kapal juga dipengaruhi oleh block coefficient $(\mathrm{Cb})$ dari kapal tersebut. Semakin kecil nilai $\mathrm{Cb}$, maka semakin besar rasio minimum lebar dan sarat kapal yang dibutuhkan untuk memenuhi kriteria stabilitas IMO khususnya sudut kemiringan dimana lengan stabilitas maksimum terjadi.

Berdasarkan hasil kajian Jin et al. (2002) dan Wang et al. (2005) menunjukkan bahwa kecelakaan kapal yang terjadi, lebih sering berupa terbaliknya kapal. Kondisi ini disebabkan karena kapal mengangkut muatan yang melebihi kapasitas muatnya, dan penempatan muatan yang berlebihan di atas lantai dek kapal.

Tabel 5 Sampel rasio terhadap parameter

\begin{tabular}{cccccc}
\hline Criteria & Value & $\begin{array}{c}\mathbf{( B / d )} \\
\mathbf{2 , 7 6}(\mathbf{U})\end{array}$ & $\begin{array}{c}\mathbf{( B / d )} \\
\mathbf{2 , 7 6} \\
\text { (hardchin })\end{array}$ & Units & Status \\
\hline Area 0 to 30 & 3,1513 & 7,2325 & 7,5519 & $\mathrm{~m} . \mathrm{deg}$ & Pass \\
Area 0 to 40 & 5,1566 & 11,9984 & 12,2555 & $\mathrm{~m} . \mathrm{deg}$ & Pass \\
Area 30 to 40 & 1,7189 & 4,7658 & 4,7036 & $\mathrm{~m} . \mathrm{deg}$ & Pass \\
Max GZ at 30 or greater & 0,200 & 0,509 & 0,480 & $\mathrm{~m}$ & Pass \\
Angle of maximum GZ & 25,0 & 45,5 & 39,1 & deg & Pass \\
Initial GMt for vessels $>=$ & 0,350 & 1,008 & 1,021 & $\mathrm{~m}$ & Pass \\
24m in length & & & & & \\
\hline
\end{tabular}

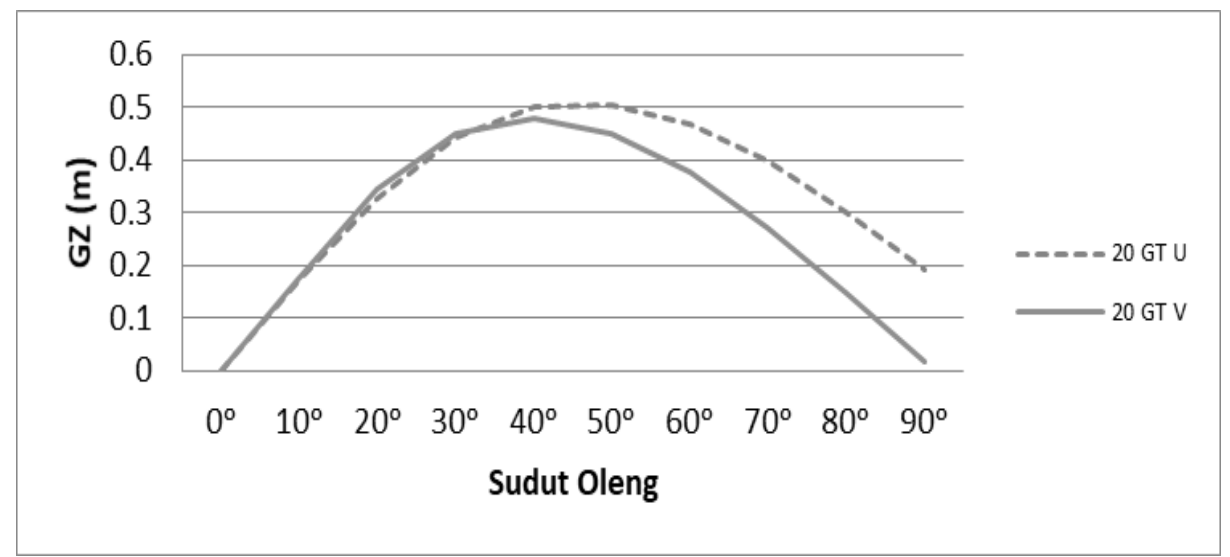

Gambar 3 Perbandingan lengan stabilitas kapal 20 GT

Tabel 6 Kriteria IMO terhadap kapal ikan 20 GT tipe U

\begin{tabular}{|c|c|c|c|c|c|}
\hline Code & Criteria & Value & Units & Actual & Status \\
\hline A.749(18) Ch3 & $\begin{array}{l}3.1 .2 .1 \text { : Area } 0 \text { to } \\
30\end{array}$ & 3,1513 & m.deg & 7,2325 & Pass \\
\hline A.749(18) Ch3 & $\begin{array}{l}\text { 3.1.2.1: Area } 0 \text { to } \\
40\end{array}$ & 5,1566 & m.deg & 11,9984 & Pass \\
\hline A.749(18) Ch3 & $\begin{array}{l}\text { 3.1.2.1: Area } 30 \text { to } \\
40\end{array}$ & 1,7189 & m.deg & 4,7658 & Pass \\
\hline A.749(18) Ch3 & $\begin{array}{l}\text { 3.1.2.2: Max GZ at } \\
30 \text { or greater }\end{array}$ & 0,200 & M & 0,509 & Pass \\
\hline A.749(18) Ch3 & $\begin{array}{l}\text { 3.1.2.3: Angle of } \\
\text { maximum GZ }\end{array}$ & 25,0 & Deg & 45,5 & Pass \\
\hline $\begin{array}{l}4.2 \text { Fishing } \\
\text { vessel }\end{array}$ & $\begin{array}{l}\text { 4.2.3.1: Initial GMt } \\
\text { for vessels }>=24 \mathrm{~m} \\
\text { in length }\end{array}$ & 0,350 & $\mathrm{~m}$ & 1,008 & Pass \\
\hline
\end{tabular}


Tabel 7 Kriteria IMO terhadap kapal ikan 20 GT tipe hardchin

\begin{tabular}{|c|c|c|c|c|c|}
\hline Code & Criteria & Value & Units & Actual & Status \\
\hline A.749(18) Ch3 & $\begin{array}{c}\text { 3.1.2.1: Area } 0 \text { to } \\
30\end{array}$ & 3,1513 & m.deg & 5,5329 & Pass \\
\hline A.749(18) Ch3 & $\begin{array}{c}\text { 3.1.2.1: Area } 0 \text { to } \\
40\end{array}$ & 5,1566 & m.deg & 8,9010 & Pass \\
\hline A.749(18) Ch3 & $\begin{array}{l}\text { 3.1.2.1: Area } 30 \text { to } \\
40\end{array}$ & 1,7189 & m.deg & 3,3681 & Pass \\
\hline A.749(18) Ch3 & $\begin{array}{l}\text { 3.1.2.2: Max GZ at } \\
30 \text { or greater }\end{array}$ & 0,200 & $\mathrm{~m}$ & 0,340 & Pass \\
\hline A.749(18) Ch3 & $\begin{array}{l}\text { 3.1.2.3: Angle of } \\
\text { maximum GZ }\end{array}$ & 25,0 & deg & 34,5 & Pass \\
\hline 4.2 Fishing vessel & $\begin{array}{l}\text { 4.2.3.1: Initial GMt } \\
\text { for vessels }>=24 \mathrm{~m} \\
\text { in length }\end{array}$ & 0,350 & $\mathrm{~m}$ & 0,714 & Pass \\
\hline
\end{tabular}
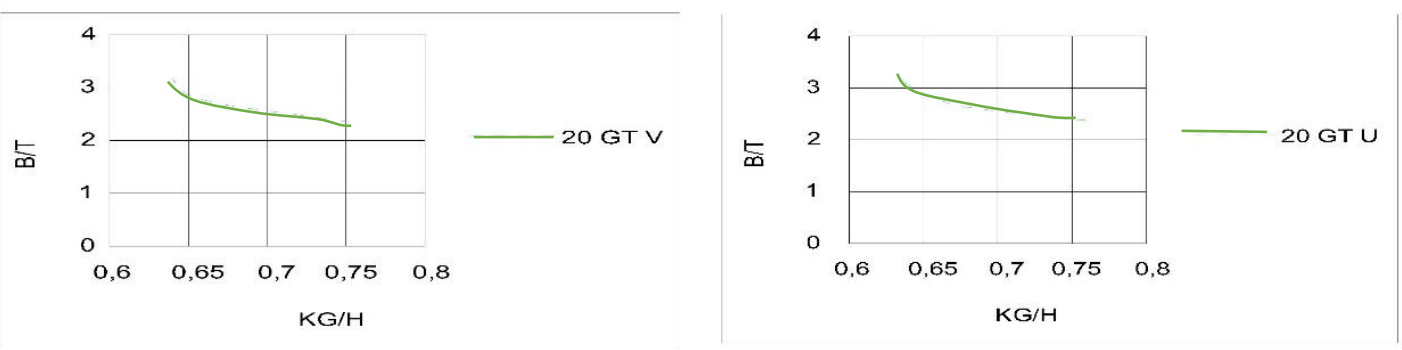

Gambar 4 Rasio KG kapal tipe U dan hardchin

\section{Pengaruh Rasio Lebar dan Sarat Terhadap Hambatan Kapal}

Bentuk lambung kapal di bawah garis air akan mempengaruhi karakteristik aliran fluida di sekitar kapal, sehingga menyebabkan resistensi meningkat atau berkurang. Jika terjadi peningkatan resistensi, ukuran mesin utama dan konsumsi bahan bakar meningkat. Hal ini sering tidak diantisipasi oleh perancang dan operator kapal (Samuel et al. 2015). Kapal yang sedang bergerak memiliki hambatan yang diterima oleh lambung kapal, yang berada di bawah garis air. Jumlah hambatan ini akan diubah menjadi sebuah tenaga yang dibutuhkan oleh kapal untuk bergerak. Adapun hambatan keseluruhan (total resistance) kapal adalah jumlah dari hambatan gesek (Rf) dengan hambatan sisa (Rr) yang terjadi pada kapal (Nooryadi dan Suastika 2012).

Hasil perhitungan hambatan untuk masing-masing kapal sampel untuk setiap rasio lebar dan sarat kapal ditunjukkan pada Gambar 5. Pada Gambar 5 menunjukkan rasio yang paling kecil memiliki hambatan yang besar. Ini berarti bahwa semakin besar rasio lebar dan sarat kapal $(B / d=3,16)$, semakin kecil hambatan yang diala-mi kapal tersebut. Makin kecil sarat kapal, hambatan akan semakin mengecil sehingga menjadikan kapal lebih efisien dalam melakukan operasi penangkapan. $\mathrm{Hal}$ ini terjadi karena pengaruh luas permukaan bidang basah kapal (wetted surface area /WSA) menjadi lebih kecil seiring dengan besarnya rasio lebar dan sarat kapal (B/d).

Besar kecilnya WSA dipengaruhi oleh ketinggian sarat (d) kapal itu sendiri. Jika d kapal kecil, maka WSA akan kecil tetapi jika d besar maka WSA akan semakin besar. Ini juga terdapat dalam rumus yang dikembangkan oleh Holtrop, dimana WSA atau S mempengaruhi nilai dari hambatan total kapal itu sendiri (Dariansyah et al. 2017). Nilai hambatan total yang rendah, diperoleh dengan cara memper-baiki bentuk bidang garis air sehingga dapat mencegah terjadinya Eddy making yang menyebabkan hambatan gelombang (Berlian dan Wempi 2011).

\section{Perbandingan Hambatan Kapal Tipe $U$ dan hardchin}

Rasio yang digunakan untuk masingmasing tipe kapal adalah pada saat desain sarat maksimum ketika kapal berlayar yaitu rasio $\mathrm{B} / \mathrm{d}$ pada 2,76 . Untuk mengetahui apakah hambatan tipe $U$ atau hardchin yang paling baik, kedua tipe tersebut dibandingkan dengan rasio yang sama.

Manopo (2012) menjelaskan bahwa bentuk kasko mempengaruhi tahanan kapal. Menurut Novita (2006), bentuk hardchin bottom atau $\mathrm{V}$ bottom memiliki tahanan kapal yang lebih 
kecil jika dibandingkan dengan bentuk $\mathrm{U}$, round bottom ataupun round flat bottom. Tahanan gerak yang kecil akan menghasilkan kecepatan laju kapal yang tinggi. Kondisi ini dibuktikan dari grafik hambatan gerak kapal yang disajikan pada Gambar 6.

Gambar 6 menunjukkan bahwa semakin tinggi kecepatan kapal, nilai hambatan gerak semakin besar. Nilai hambatan gerak kapal dengan lambung tipe $U$ dan hardchin hingga kecepatan 12 knots memiliki nilai yang sama. Artinya kedua bentuk lambung kapal hingga kecepatan 12 knots, masih memiliki respon yang sama terhadap aliran air yang mengenai kapal saat bergerak. Akan tetapi, saat kapal bergerak dengan kecepatan di atas 12 knots, hambatan gerak kapal dengan lambung $U$ memiliki hambatan gerak yang lebih besar dibandingkan tipe hardchin. Kondisi ini diperkirakan terjadi karena pada saat kapal dengan lambung hardchin bergerak dengan kecepatan di atas 12 knots, posisi kapal terhadap permukaan air agak terangkat khususnya di bagian haluan kapal. Terangkatnya sebagian badan kapal yang terendam air, diakibatkan karena lambung kapal tipe hardchin lebih ramping. Adapun kapal dengan lambung $\mathrm{U}$, dengan bentuk lambung kapal yang lebih gemuk mengakibatkan posisi kapal terhadap air lebih konstan. Kecilnya nilai hambatan gerak, pada akhirnya juga menjadikan pengoperasian kapal menjadi lebih hemat bahan bakar sebagaimana dikatakan oleh Sunardi et al. (2015).

Tabel 8 Perbandingan WSA

\begin{tabular}{ccccccc}
\hline \multicolumn{2}{c}{ Rasio (B/d) } & 2,36 & 2,56 & 2,76 & 2,96 & 3,16 \\
\hline \multirow{2}{*}{ WSA $\left(\mathrm{m}^{2}\right)$} & 20 GT U & 75 & 71 & 68 & 65 & 61.235 \\
& 20 GT hardchin & 74,36 & 70,05 & 66,48 & 63 & 59,23 \\
\hline
\end{tabular}

Tabel 9 WSA Vs resistance

\begin{tabular}{cccccc}
\hline \multicolumn{7}{c}{$20 \mathrm{GT} \mathrm{U}$} \\
\hline WSA $\left(\mathrm{m}^{2}\right)$ & 75 & 71 & 68 & 65 & 61.235 \\
Resistance $(\mathrm{KN})$ & 12,3 & 10,8 & 7,3 & 7 & 6,4 \\
\hline WSA $\left(\mathrm{m}^{2}\right)$ & 74.355 & 20 GT hardchin & & & \\
\hline Resistance $(\mathrm{KN})$ & 11,1 & 9,047 & 66.477 & 63 & 59.23 \\
\hline
\end{tabular}
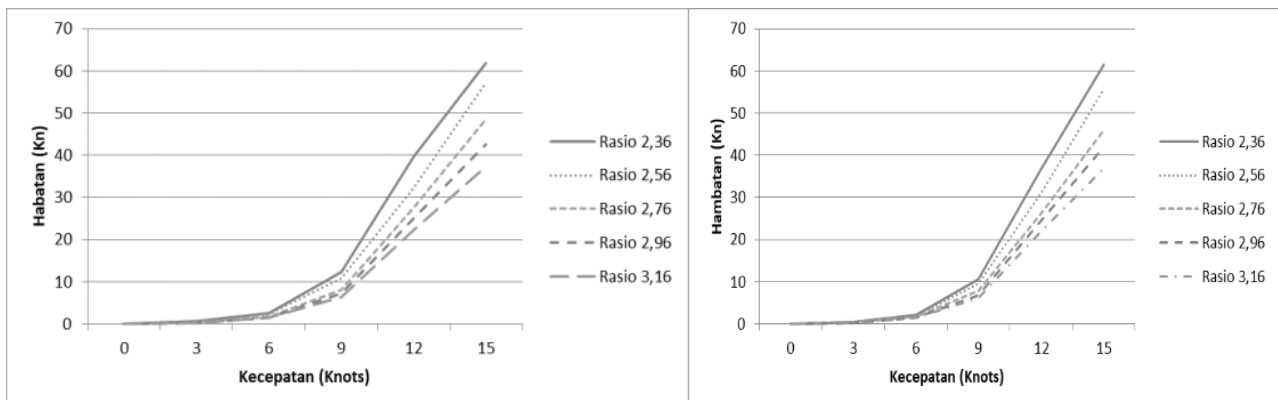

Gambar 5 Kurva hambatan vs kecepatan 20 GT U dan V

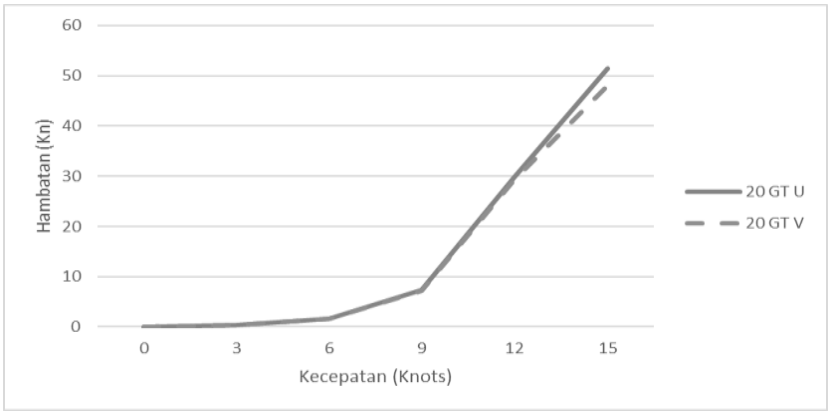

Gambar 6 Perbandingan hambatan kapal 20 GT 


\section{Seakeeping}

Gerakan kapal saat beroperasi di perairan memiliki pengaruh dan peranan yang penting terutama pada kelayakan laut kapal (seaworthiness). Kapal dinyatakan tidak layak laut, maka salah satu aspek ketidaklayakan tersebut adalah aspek hidrodinamika berkualitas buruk yang menyebabkan kapal dan awak kapal akan mengalami hal-hal buruk; menimbulkan kerugian materil dan korban jiwa (O'Hanlon et al. 1974).

Beberapa contoh akibat yang timbul karena gerakan kapal yang buruk misalnya kapal terbalik akibat inklinasi yang berlebihan saat terjadi gerakan rolling, kerusakankerusakan pada konstruksi badan kapal atau konstruksi lainnya akibat adanya gaya-gaya tambahan yang timbul, dan lain-lain (Hutauruk dan Rengi 2014).

Kapal penangkap ikan umumnya beroperasi di perairan terbuka, di mana musim tertentu mengalami gelombang dan badai yang mempengaruhi operasi kapal. Kondisi lingkungan ini mempengaruhi pergerakan kapal yang pada gilirannya dapat menyebabkan kondisi awak kapal menurun (Rahman et al. 2015). Gelombang laut menyebabkan kapal merespon dalam bentuk pergerakan kapal atau seakeeping. Gerak kapal itu akan mempengaruhi kinerja dan kenyamanan awak kapal (Rudiyansyah et al. 2013). Efek dari kinerja seakeeping pada kenyamanan awak kapal terkait erat dengan percepatan vertikal dan horizontal yang dialami. Ketidaknyamanan yang disebabkan oleh mabuk laut sebagai hubungan antara variabel percepatan, frekuensi percepatan dan durasi percepatan (O'Hanlon et al.1974).

Tabel 10, 11 dan 12 untuk kapal 20 GT tipe $U$, ada yang tidak memenuhi kriteria berdasarkan Tello et al. (2010). Pada kondisi following seas kapal hanya mampu beroperasi baik pada ketinggian gelom-bang dibawah 2 meter karena $R M S$ of Pitch pada ketinggian lebih dari 2 meter melebihi standar. Pada saat kondisi beam seas kapal hanya mampu beroperasi baik pada ketinggian kurang dari 1,5 meter karena RMS of Roll pada ketinggian lebih dari 1,5 meter melebihi standar. Pada kondisi head seas, RMS of Vertical Acceleration dengan ketinggian gelombang lebih dari 2,5 meter diatas standar. Kapal ikan 20 GT tipe U mampu beroperasi dengan baik pada per-airan di Indonesia yang tinggi gelombangnya berkisar diantara 0,5-1,5 meter.

Tabel 10 Seakeeping kapal 20 GT (U) pada Following Seas

\begin{tabular}{cccccc}
\hline $\mathrm{A}$ & $\mathrm{B}$ & $\mathrm{C}$ & $\mathrm{d}$ & $\mathrm{e}$ & $\mathrm{f}$ \\
\hline 0,5 & $0,037 \& 0,019$ & 0 & 0,64 & 0 & Pass \\
1 & $0,074 \& 0,039$ & 0 & 0,128 & 0 & Pass \\
1,5 & $0,112 \& 0,058$ & 0 & 0,192 & 0 & Pass \\
2 & $0,149 \& 0,078$ & 0 & 0,256 & 0 & Pass \\
2,5 & $0,186 \& 0,097$ & 0 & 0,32 & 0 & Fail \\
3 & $0,223 \& 0,117$ & 0 & 0,385 & 0 & Fail \\
\hline
\end{tabular}

Tabel 11 Seakeeping kapal 20 GT (U) pada Beam Seas

\begin{tabular}{cccccc}
\hline $\mathrm{A}$ & $\mathrm{B}$ & $\mathrm{C}$ & $\mathrm{d}$ & $\mathrm{e}$ & $\mathrm{f}$ \\
\hline 0,5 & $0,163 \& 0,099$ & $0,257 \& 0,21$ & 0,28 & 1,67 & Pass \\
1 & $0,326 \& 0,198$ & $0,514 \& 0,42$ & 0,57 & 3,34 & Pass \\
1,5 & $0,488 \& 0,298$ & $0,771 \& 0,63$ & 0,85 & 5,01 & Pass \\
2 & $0,651 \& 0,397$ & $1,028 \& 0,840$ & 1,14 & 6,68 & Fail \\
2,5 & $0,814 \& 0,496$ & $1,285 \& 1,050$ & 1,42 & 8,35 & Fail \\
3 & $0,977 \& 0,595$ & $1,541 \& 1,259$ & 1,71 & 10,02 & Fail \\
\hline
\end{tabular}

Tabel 12 Seakeeping kapal 20 GT (U) pada Head Seas

\begin{tabular}{cccccc}
\hline $\mathrm{A}$ & $\mathrm{B}$ & $\mathrm{c}$ & $\mathrm{d}$ & $\mathrm{e}$ & $\mathrm{f}$ \\
\hline 0,5 & $0,276 \& 0,410$ & 0 & 0,52 & 0 & Pass \\
1 & $0,553 \& 0,82$ & 0 & 1,04 & 0 & Pass \\
1,5 & $0,828 \& 1,23$ & 0 & 1,56 & 0 & Pass \\
2 & $1,106 \& 1,640$ & 0 & 2,08 & 0 & Pass \\
2,5 & $1,382 \& 2,050$ & 0 & 2,60 & 0 & Pass \\
3 & $1,659 \& 2,460$ & 0 & 3,12 & 0 & Fail \\
\hline
\end{tabular}


Tabel 13, 14 dan 15 untuk kapal 20 GT tipe hardchin didapat bahwa ada yang tidak memenuhi kriteria dari Tello (2010). Pada kondisi following seas kapal hanya mampu beroperasi baik pada ketinggian gelombang kurang dari 2 meter karena RMS of Pitch pada ketinggian lebih dari 2 meter melebihi standar. Pada saat kondisi beam seas kondisi gelombang lebih dari 1,5 meter, roll motion tidak memenuhi kriteria yang seharusnya. Menurut Tello (2010) roll motion harus kurang dari $6^{\circ}$, akan tetapi pada kondisi ini kapal melebihi standar dan hanya mampu beroperasi baik pada ketinggian kurang dari 1,5 meter. Pada kondisi head seas, RMS of Vertical Acceleration dengan ketinggian gelombang lebih dari 2,5 meter melebihi standar yang ditetapkan oleh Tello (2010).

Dari analisis, dapat disimpulkan pada kriteria roll dan pitch kapal dapat melewatinya.
Bentuk lambung berpengaruh pada gerakan kapal akibat roll motion dimana tipe $U$ lebih aman daripada tipe $\mathrm{V}$ (Tello et al. 2011). Dengan demikian perancangan olah gerak kapal (seakeeping) harus melingkupi habitability yang berhubungan dengan lingkungan di mana kru kapal bisa melaksanakan tugasnya secara efektif sehingga tidak ada penurunan performa kerja kru/nelayan akibat adanya gerakan-gerakan kapal (Hutauruk dan Rengi 2014).

Penting untuk menilai kinerja seakeeping sehingga kapal dapat menghindari kecelakaan. Untuk kapal penangkap ikan harus memiliki kinerja seakeeping yang baik, tidak menginginkan untuk memiliki amplitudo gerak yang berlebihan, karena akan menyebabkan tugas-tugas kapal onboard menjadi berbahaya dan mengurangi efisiensi kru, sehingga mengham-bat pengoperasian alat tangkap (Yakob et al. 2015).

Tabel 13 Seakeeping kapal 20 GT (hardchin) pada Following Seas

\begin{tabular}{cccccc}
\hline $\mathrm{A}$ & $\mathrm{B}$ & $\mathrm{C}$ & $\mathrm{d}$ & $\mathrm{e}$ & $\mathrm{f}$ \\
\hline 0,5 & $0,039 \& 0,041$ & 0 & 0,66 & 0 & Pass \\
1 & $0,078 \& 0,082$ & 0 & 1,32 & 0 & Pass \\
1,5 & $0,117 \& 0,123$ & 0 & 1,98 & 0 & Pass \\
2 & $0,155 \& 0,164$ & 0 & 2,64 & 0 & Pass \\
2,5 & $0,194 \& 0,205$ & 0 & 3,3 & 0 & Fail \\
3 & $0,233 \& 0,246$ & 0 & 3,96 & 0 & Fail \\
\hline
\end{tabular}

Tabel 14 Seakeeping kapal 20 GT (hardchin) pada Beam Seas

\begin{tabular}{cccccc}
\hline $\mathrm{A}$ & $\mathrm{B}$ & $\mathrm{C}$ & $\mathrm{d}$ & $\mathrm{e}$ & $\mathrm{f}$ \\
\hline 0,5 & $0,152 \& 0,107$ & $0,301 \& 0,246$ & 0,29 & 1,68 & Pass \\
1 & $0,305 \& 0,214$ & $0,601 \& 0,492$ & 0,59 & 3,36 & Pass \\
1,5 & $0,457 \& 0,322$ & $0,902 \& 0,738$ & 0,88 & 5,04 & Pass \\
2 & $0,610 \& 0,429$ & $1,203 \& 0,984$ & 1,18 & 6,72 & Fail \\
2,5 & $0,762 \& 0,536$ & $1,504 \& 1,229$ & 1,47 & 8,4 & Fail \\
3 & $0,915 \& 0,643$ & $1,804 \& 1,475$ & 1,76 & 10,08 & Fail \\
\hline
\end{tabular}

Tabel 15 Seakeeping kapal 20 GT (V) pada Head Seas

\begin{tabular}{cccccc}
\hline $\mathrm{a}$ & $\mathrm{B}$ & $\mathrm{c}$ & $\mathrm{d}$ & $\mathrm{e}$ & $\mathrm{f}$ \\
\hline 0,5 & $0,251 \& 0,437$ & 0 & 0,52 & 0 & Pass \\
1 & $0,502 \& 0,874$ & 0 & 1,04 & 0 & Pass \\
1,5 & $0,753 \& 1,311$ & 0 & 1,56 & 0 & Pass \\
2 & $1,004 \& 1,748$ & 0 & 2,08 & 0 & Pass \\
2,5 & $1,255 \& 2,185$ & 0 & 2,60 & 0 & Pass \\
3 & $1,506 \& 2,622$ & 0 & 3,12 & 0 & Fail \\
\hline
\end{tabular}

Keterangan:

RMS = Root Mean Square

a : Tinggi Gelombang (m)

$\mathrm{b}:$ RMS of Vertical Acceleration (at Working Deck AP \& FP)

c : RMS of Lateral Acceleration (at Working Deck Ap \& FP)

$\mathrm{d}:$ RMS of Pitch

e : RMS of Roll dan

$f:$ Status 


\section{KESIMPULAN}

Makin besar rasio lebar dan tinggi kapal, stabilitas kapal semakin baik dimana titik berat maksimum yang memenuhi kriteria stabilitas IMO juga menjadi semakin besar. Kapal dengan sarat yang lebih besar akan mempunyai stabilitas yang lebih baik untuk rasio lebar dan sarat kapal yang sama. Rasio lebar dan sarat kapal minimum yang memenuhi kriteria stabilitas adalah 2,50. Stabilitas lambung kapal tipe U lebih baik dari pada tipe hardchin. Makin Besar nilai B/d kapal makin kecil hambatan yang dialami kapal jika hanya draft sebagai pengubah rasionya. Hambatan lambung dengan tipe hardchin lebih kecil dibandingkan dengan tipe U. Seakeeping kapal dengan lambung tipe hardchin lebih baik dari pada tipe $U$ saat beroperasi di tinggi gelombang yang sama.

\section{SARAN}

Kapal pada penelitian ini disarankan beroperasi pada perairan dengan tinggi gelom-bang sama dengan atau dibawah dari 1,5 m. Rasio lebar dan sarat kapal minimum yang diteliti untuk kapal ikan disarankan tidak kurang dari 2,50. Rasio lebar dan sarat kapal minimum yang diteliti untuk kapal ini disa-rankan tidak lebih dari 0,14 .

\section{UCAPAN TERIMA KASIH}

Ucapan terima kasih ditukjukan ke-pada LP2MK-UNSADA yang telah mendanai terlaksananya penelitian ini dengan nomor kontrak penelitian 032/PEN/LP2MK/UNSADA/V/2017

\section{DAFTAR PUSTAKA}

Bačkalov I, Bulian B, Cichowicz J. 2016. Ship Stability, Dynamics and Safety: Status and Perspectives from are View of Recent STAB Conferences and ISSW Events. Ocean Engineering. 116(6): 312-349.

Berlian A, Wempi A. 2011. Analisa Kinerja Hull form Metode form Data Kapal Ikan Tradisional 28 GT Km. Sido Sejati. Kapal. 8(1): 35-40.

Boulougouris E, Cichowicz J, Jasionowski A, Konovessis D. 2016. Improvement of Ship Stability and Safety in Damaged Condition Through Operational Measures: Challenges and Opportunities. Ocean Engineering. 122(12): 311-316.

Caamano LS, Gonzalez MM, Casas VD. 2016. On the Feasibility of a Real Time Stability
Assessment for Fishing Vessels. Ocean Engineering. 159(13): 76-87.

Dariansyah MR, Iskandar BH, Novita Y. 2017. Bentuk Kasko dan Pengaruhnya terhadap Kapasitas Volume Ruang Muat dan Tahanan Kasko. ALBACORE. 1(3): 265-276.

Fyson J. 1985. Design of Small Fishing Vessels. England: Fishing News Book. Pages: 2153.

Hasselmann K, TP Barnett, E Bouws, H Carlson, DE Cartwright, $\mathrm{K}$ Enke, JA Ewing, $\mathrm{H}$ Gienapp, DE Hasselmann, P Kruseman, A Meerburg, P Mller, DJ Olbers, K Richter, W Sell, H Walden. 1978. Measurements of Wind-Wave Growth and Swell Decay During the Joint North Sea Wave Project (JONSWAP)' Ergnzungsheft zur Deutschen Hydrographischen Zeitschrift Reihe. 8(12): 95.

Holtrop J, Mennen GGJ. 1982. A Statistical Power Prediction Method. International Shipbuilding Progress. 25(28): 166-170.

Hutauruk RM, Rengi P. 2014. Respons Gerakan Kapal Perikanan Hasil Optimasi terhadap Gelombang. Jurnal Perikanan dan Kelautan. 19(1): 13-22.

International Maritime Organization (IMO). 2008: Stability Kriteria for Fishing Vessel, International Maritime Organization, London.

Jin D, Kite-Powell HL, Thunberg E, Solow AR, Talley WK. 2002. A Model of Fishing Vessel Accident Probability. Journal of Safety Research. 33(4): 497-510.

Jung SK, Roh MI, Kim KS. 2018. Arrangement Method of a Naval Surface Ship Considering Stability, Operability, and Survivability. Journal Ocean Engineering. 152(6): 316-333.

Krata P. 2008. Total Losses of Fishing Vessels Due to the Insufficient Stability. International Journal on Marine Navigation and Safety of Sea Transportation. 2(3): 311315.

Tello M, e Silva SR, Soares CG. 2010. Seakeeping Performance of Fishing Vessels in Irregular Waves. Portugal: Centre for Marine Technology and Engi-neering (CENTEC), Technical University of Lisbon, Instituto Superior Te'cnico, Av. Rovisco Pais. 38(5): 763-773.

Tello M, e Silva SR, Soares CG. 2011. Seakeeping Performance of Fishing Ve- 
ssels in Irregular Waves. Ocean Engineering. 38(6): 763-773.

Manopo AR. 2012. Studi Pengaruh Bentuk Kasko pada Tahanan Kapal Pukat Cincin di Tumumpa, Bitung, dan Molibagu (Provinsi Sulawesi Utara). Jurnal IImu dan Teknologi Perikanan Tangkap. 1(2): 6368.

Mantari JL, Ribeiro ES, Soaresn CG. 2011. Intact Stability of Fishing Vessels Under Combined Action of Fishing Gear, Beam Waves and Wind. Ocean Engineering 38(17): 1989-1999.

Nooryadi L, Suastika K. 2012. Perhitungan Wave Making Resistance pada Kapal Katamaran dengan Menggunakan CFD. Jurnal Teknik ITS. 1(1): 30-34.

Novita Y. 2006. Studi Tentang Bentuk Kasko Kapal Ikan di Beberapa Daerah di Indonesia. Jurnal IImu kelautan dan Perikanan. 16(4): 240-249.

Novita Y, Martiyani N, Ariyani RE. 2014. Kualitas Stabilitas Kapal Payang Palabuhanratu Berdasarkan Distribusi Muatan. Jurnal IPTEKS PSP. 1(1): 28-39.

O'Hanlon JF, McCauley ME.1974. Motion Sickness Incidence as a Function of the Frequency and Acceleration of Vertical Sinusoidal Motion. Aerospace Medicine. 45(4): 366-375.

Paroka D. 2018. Karakteristik Geometri dan Pengaruhnya Terhadap Stabilitas Kapal Ferry Ro-Ro Indonesia. Jurnal IImu Pengetahuan \& Teknologi Kelautan. 15(1): 1-8.

Rahman S, Haris MA, Paroka D. 2015. Seakeeping Kapal Perikanan 30 GT di Perairan Selat Makassar. Seminar Teknologi dan Rekayasa (SENTRA) 2015. 1(1): 6469.
Rawson KJ, Tupper EC. 1983. Basic Ship Theory "Ed ke-3". London: Butterworth-Heinemann.

Rouf ARA, Y Novita. 2006. Studi Tentang Bentuk Kasko Kapal Ikan di Beberapa Daerah di Indonesia. Jurnal Torani (Journal of Marine Fisheries and Marine Science). 16(4): 51-62.

Rudiyansyah H, Sulisetyono A, Ali B. 2013. Analisa Pengaruh Seakeeping terhadap Kinerja dan Kenyamanan Kapal RO-PAX Berbasis Uji Model di Perairan Laut Jawa. Jurnal Teknik POMITS. 2(1): 1-7.

Samuel, Iqbal M, Utama IKAP. 2015. An Investigation Into the Resistance Components of Converting A Traditional Monohull Fishing Vessel Into Catamaran Form. International Journal of Technology. 6(3): 432-441.

Sunardi, Efani A, Muzakky LO. 2015. Design of Eco-Friendly Shallow Draft Fishing Vessel. Research Journal of Life Science. 2(3): 199-204.

Susanto A, Iskandar BH, Imron M. 2011. Evaluasi Desain dan Stabilitas Kapal Penangkap Ikan di Palabuhanratu : Studi Kasus Kapal PSP 01. Jurnal Marine Fisheries. 2(2): 213-221.

Wang JA, Pillay YS, Kwon AD, Wall, Loughran CG. 2005. An Analysis of Fishing Vessel Accidents. Accident Analysis \& Prevention. 37(6): 1019-1024.

Yakob O, Ellyza HF, Rajali JM, Adli MM. 2015. Stability, Seakeeping and Safety Assessment of Small Fishing Boats Operating in Southern Coast of Peninsular Malaysia. Journal of Sustainability Science and Management. 10(1): 50-56. 